Jurnal Teknik Komputer AMIK BSI

Volume VI No.1 Januari 2020

P-ISSN 2442-2436, E-ISSN: 2550-0120

Akreditasi Ristekdikti, No: 21/E/KPT/2018

DOI: $10.31294 / j$ tk.v4i2

\title{
Penerapan Algoritma Naïve Bayes Dalam Penentuan Kelayakan Penerima Kartu Jakarta Pintar Plus
}

\author{
Endah Widya Ningsih ${ }^{1}$, Hardiyan ${ }^{2}$ \\ ${ }^{1}$ STMIK Nusa Mandiri \\ e-mail: endah_widya@yahoo.com \\ ${ }^{2}$ Universitas Bina Sarana Informatika \\ e-mail: hardiyan.hry@bsi.ac.id
}

\begin{abstract}
Abstrak - Kelayakan penerima Kartu Jakarta Pintar Plus masih belum tepat sasaran dikarenakan penerimaan yang masih bersifat subjektif. Pihak sekolah berperan penting dalam pengambilan keputusan kelayakan penerima Kartu Jakarta Pintar Plus. Oleh karenanya, peneliti membuat penelitian ini dengan menggunakan data yang sudah ada sebelumnya atau disebut dengan data training. Peneliti menggunakan metode Naïve Bayes dengan 7 atribut yang saling independen untuk menentukan kelayakan. Peneliti juga menggunakan aplikasi pendukung Rapidmined 5.3 untuk menguji keakurasian metode Nä̈ve Bayes. Pengujian dilakukan dengan 134 data training dan 34 data testing. Hasil pengujian akurasi penentuan kelayakan penerima Kartu Jakarta Pintar Plus dengan Algoritma Nä̈ve Bayes cukup baik, yaitu 98,88\% dengan presentasi eror 2,22\%. Jadi, dapat disimpulkan bahwa metode Nä̈ve Bayes dapat membantu penentuan kelayakan penerima Kartu Jakarta Pintar Plus.
\end{abstract}

Kata Kunci: Kartu Jakarta Pintar, Nä̈ve Bayes, Kelayakan

Abstract The eligibility of Jakarta Smart CardPlus recipients is still not on target due to subjective receipts. Schools has an important role in making decisions about the eligibility of Jakarta Smart Plus Card recipients. Therefore, the authors make this research using data that already exists or is called training data. The author uses the Nä̈ve Bayes method with 7 independent attributes to knowing eligibility. The author also uses the another application Rapidmined 5.3 to test the accuracy of the Nä̈ve Bayes method. The result of this research the accuracy of determining the eligibility of Jakarta Smart Plus Card recipients are good with 98.88\% with an error of presentation $2.22 \%$. So it can be concluded that the naive bayes method can help detrermine the eligibility of jakarta smart plus card recipients.

Keywords: Jakarta Smart Card, Nä̈ve Bayes, eligibility

\section{PENDAHULUAN}

Pendidikan di Indonesia diwajibkan 12 tahun, tetapi masih banyak masyarakat yang tidak bisa sekolah karena adanya kendala biaya.Oleh karenanya, DKI Jakarta mempunyai program yang dapat membantu warga kurang mampu.Program ini bernama Kartu Jakarta Pintar Plus (KJP Plus) yang diberikan kepada para siswa khususnya untuk siswa SD Negri Kembangan Utara 09 Pagi.

Banyaknya antusias dari siswa SDN Kembangan Utara 09 Pagi sehingga banyak yang ingin mendaftar untuk mendapatkan Kartu Jakarta Pintar.Karena kendala waktu yang hanya 1 (satu) bulan, pihak sekolah tidak menyeleksi terlebih dahulu data-data yang ada sehingga terlalu banyak data yang diinput pada sistem Kartu Jakarta Pintar Plus (KJP Plus) yang dilakukan oleh admin.

Menurut Saryoko (2017) mengatakan bahwa, "Proses penerimaan Kartu Jakarta Pintar (KJP) masih bersifat subyektif". Hal ini tentu tidak efektif, oleh karenanya penelitiakan menggunakan Algoritma Nä̈ve Bayes untuk menyeleksi siswa siswi sesuai kriteria untuk menentukan siapa yang layak mendapatkan Kartu Jakarta Pintar Plus (KJP Plus). Menurut Han dan Kamber dalam Putri, Suparti, \& Rahmawati (2014), "Nä̈ve Bayes terbukti memiliki akurasi dan kecepatan yang tinggi saat diaplikasikan ke dalam basis data dengan jumlah yang besar".

Menurut Dahri, Agus, \& Khairina (2016), "Algoritrma Nä̈ve Bayes merupakan probabilistik 
pengklasifikasian sederhana berdasarkan Teorema Bayes dimana pengklasifikasian dilakukan melalui training set sejumlah data secara efisien".

\section{METODOLOGI PENELITIAN}

Peneliti melakukan analisa menggunakan data siswa yang didapatkan langsung dari SDN Kembangan Utara 09 Pagi. Data yang peneliti dapat berjumlah 168 data calon penerima Kartu Jakarta Pintar Plus (KJP Plus) yang terdiri dari 30 kriteria. Peneliti akan melakukan beberapa penyeleksian untuk menghasilkan data yang dibutuhkan, tahapannya yaitu:

a. Data Cleaning pada tahap ini peneliti membersihkan nilai yang kosong atau tuple yang kosong.

b. Data Integration pada tahap ini penelitimenggabungkan beberapa data dari berbagai dataset ke dalam dataset baru.

c. Data Reduction berfungsi menghilangkan data yang tidak dibutuhkan.

Peneliti melakukan seleksi pada jumlah atribut yang terlalu banyak dan tidak semua atribut menjadi syarat atas atribut penentu, sehingga yang digunakan hanya 8 atribut diantaranya pendidikan kepala rumah tangga, status pekerjaan kepala rumah tangga, penghasilan kepala rumah tangga, salah satu/kedua orang tua kandung meninggal, status tempat tinggal, daya listrik (watt), luas bangunan tempat tinggal dan keterangan penerima layak atau tidak layak menerima Kartu Jakarta Pintar Plus (KJP Plus)

Dalam metode pengumpulan data pada penelitian ini peneliti menggunakan form survey calon penerima Kartu Jakarta Pintar Plus (KJP Plus) yang didapat dari SDN Kembangan Utara 09 Pagi. Populasi dalam penelitian ini adalah data form survey calon penerima Kartu Jakarta Pintar Plus (KJP Plus) di SDN Kembangan Utara dengan 2 kali pendataan disetiap tahunnya. Sampel adalah sebagian dari karakteristik yang dimiliki oleh populasi tersebut. Adapun sampel penelitian yang diambil adalah data Pendaftaran KJP pada tahap 1 yang diadakan pada tanggal 19 Februari 2019 sampai 19 Maret 2019 dengan 168 data siswa.

Metode analisa data menggunakan metode Nä̈ve Bayes yang merupakan sebuah pengklasifikasi probalitas sederhana yang mengaplikasikan Teorema Bayes dengan asumsi ketidaktergantungan (independen) yang tinggi. Keuntungan penggunaan Metode Nä̈ve Bayes adalah bahwa metode ini hanya membutuhkan jumlah data pelatihan (training data) yang kecil untuk menentukan estimasi parameter yang diperlukan dalam proses pengklasifikasian. Karena yang diasumsikan sebagai variabel independen, maka hanya varian dari suatu variabel dalam sebuah kelas yang dibutuhkan untuk menentukan klasifikasi, bukan keseluruhan. Atribut yang dibutuhkan pada penelitian ini, yaitu:

1. Pendidikan Kepala Rumah Tangga (Lebih atau lulusan SMA; Kurang dari SMA)

2. Status Pekerjaan Kepala Rumah Tangga (Tetap; Tidak Tetap/PHK)

3. Penghasilan Kepala Rumah Tangga (Cukup; Tidak Cukup)

4. Salah Satu/Kedua Orang Tua Meninggal Dunia (Ya; Tidak)

5. Status Tempat Tinggal (Milik sendiri; Sewa/Kontrak; Bebas Sewa)

6. Daya Listri (Watt) $(450 ; 900 ; 1300)$

7. Luas Bangunan Tempat Tinggal (Lebih dari $8 \mathrm{~m}^{2}$; Kurang dari $8 \mathrm{~m}^{2}$ )

Langkah-langkah algoritma Nä̈ve Bayes menurut Suntoro (2019), sebagai berikut:

1. Siapkan dataset.

2. Hitung jumlah kelas pada data training.

3. Hitung jumlah kasus yang sama dengan kelas yang sama.

4. Kalikan semua hasil sesuai dengan data testing yang akan dicari kelasnya.

5. Bandingkan hasil perkelas, nilai tertinggi ditetapkan sebagai kelas baru.

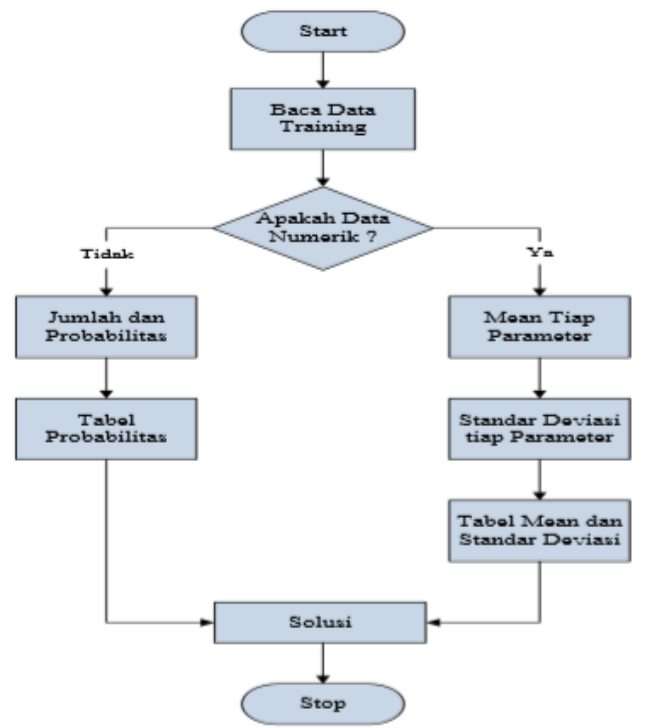

Sumber: Bustami (2014)

Gambar 1. Skema Nä̈ve Bayes

\section{HASIL DAN PEMBAHASAN}

Dataset adalah data keseluruhan yang akan diolah atau digunakan pada suatu penelitian. Data training adalah data yang digunakan untuk pembelajaran pada proses pendukung keputusan. Pada penelitian ini data training berjumlah 134 data siswa yang diambil dari $80 \%$ dataset.

Sedangkan atribut yang digunakan dalam penelitian ini berjumlah 7 atribut, dimana variabel tersebut 
merupakan variabel penentu untuk memprediksi kelayakan siswa.Atribut yang digunakan yaitu pendidikan kepala rumah tangga, status pekerjaan kepala rumah tangga, penghasilan kepala rumah tangga, salah satu/kedua orang tua meninggal dunia, status tempat tinggal, daya listrik, luas bangunan tempat tinggal dan status.Variabel status merupakan variabel yang menunjukan layak atau tidak layak nya siswa dalam menerima KJP.

\section{PerhitunganNä̈ve Bayes}

Berikut ini merupakan uraian langkah-langkah perhitungan dalam metode Nä̈ve Bayes dalam penyelesaian kasus prediksi kelayakan penerima Kartu Jakarta Pintar (KJP).

\section{a. Pembacaan Data Training}

Untuk menentukan data yang nantinya akan dianalisis dengan Metode Nä̈ve Bayes maka langkah pertama yang dilakukan adalah membaca data training. Pada penelitian ini ada 134 data training/sampel.

\section{b. Menghitung Probabilitas Kelas}

Tahap pertama perhitungan pencarian kelayakan dengan metode Nä̈ve Bayes adalah mencari probablitias dari masing-masing kelas. Untuk pendaftaran Kartu Jakarta Pintar (KJP) akan ditentukan dalam 2 kelas, yaitu kelas "Layak" dan "Tidak Layak".

Cara perhitungannya adalah dengan mencari berapa jumlah data yang layak dan tidak layak dari total keseluruhan data training, lalu membaginya dengan total keseluruhan data. Hasil dari perhitungan tersebut dapat dilihat pada table berikut:

Tabel1. Probabilitas Kelas

\begin{tabular}{|c|c|c|}
\hline \multicolumn{2}{|c|}{ Kelas } & Probabilitas \\
\hline Layak & $118 / 134$ & 0.881 \\
\hline Tidak Layak & $16 / 134$ & 0.119 \\
\hline
\end{tabular}

Sumber: Ningsih \& Hardiyan (2019)

\section{c. Menghitung Probabilitas Atribut}

Cara mencari probabilitas suatu atribut adalah dengan membandingkan atribut dari data testing dengan atribut dari data training.Berapa jumlah atribut dengan kelas layak yang berada pada data training, kemudian bagi dengan probabilitas kelas layak.Begitu juga dengan mencari probabilitas untuk kelas tidak layak.

\section{Atribut Pendidikan Kepala Rumah Tangga}

Tabel 2. Probabilitas Pendidikan Kepala Rumah

\begin{tabular}{|c|c|c|c|c|}
\hline \multicolumn{5}{|c|}{ Tangga } \\
\hline \multirow{2}{*}{$\begin{array}{c}\text { Pendidikan } \\
\text { Kepala } \\
\text { Rumah } \\
\text { Tangga }\end{array}$} & \multirow[b]{2}{*}{ Layak } & \multirow[b]{2}{*}{$\begin{array}{l}\text { Tidak } \\
\text { Layak }\end{array}$} & \multicolumn{2}{|c|}{ Probabilitas } \\
\hline & & & Layak & $\begin{array}{c}\text { Tidak } \\
\text { Layak }\end{array}$ \\
\hline
\end{tabular}

\begin{tabular}{|c|c|c|c|c|}
\hline $\begin{array}{c}\text { Lebih dari } \\
\text { SMA }\end{array}$ & $35 / 118$ & $14 / 16$ & 0.297 & 0.875 \\
\hline $\begin{array}{c}\text { Kurang dari } \\
\text { SMA }\end{array}$ & $83 / 118$ & $2 / 16$ & 0.703 & 0.125 \\
\hline
\end{tabular}

Sumber: Ningsih \& Hardiyan (2019)

\section{Atribut Status Pekerjaan Kepala Rumah Tangga}

Tabel 3.Probabilitas Status Pekerjaan Kepala Rumah Tangga

\begin{tabular}{|c|c|c|c|c|}
\hline Status & & & \multicolumn{2}{|c|}{ Probabilitas } \\
\cline { 4 - 5 } $\begin{array}{c}\text { Pekerjaan } \\
\text { Kepala } \\
\begin{array}{c}\text { Rumah } \\
\text { Tangga }\end{array}\end{array}$ & Layak & $\begin{array}{c}\text { Tidak } \\
\text { Layak }\end{array}$ & Layak & $\begin{array}{c}\text { Tidak } \\
\text { Layak }\end{array}$ \\
\hline Tetap & $48 / 118$ & $14 / 16$ & 0.407 & 0.875 \\
\hline $\begin{array}{c}\text { Tidak } \\
\text { Tetap/PHK }\end{array}$ & $70 / 118$ & $2 / 16$ & 0.593 & 0.125 \\
\hline
\end{tabular}

Sumber: Ningsih \& Hardiyan (2019)

3. Atribut Penghasilan Kepala Rumah Tangga

Tabel 4. Probabilitas Penghasilan Kepala Rumah Tangga

\begin{tabular}{|c|c|c|c|c|}
\hline Penghasilan & & & \multicolumn{2}{|c|}{ Probabilitas } \\
\cline { 4 - 5 } $\begin{array}{c}\text { Kepala } \\
\text { Rumah } \\
\text { Tangga }\end{array}$ & Layak & $\begin{array}{c}\text { Tidak } \\
\text { Layak }\end{array}$ & Layak & $\begin{array}{c}\text { Tidak } \\
\text { Layak }\end{array}$ \\
\hline Cukup & $1 / 118$ & $9 / 16$ & 0.008 & 0.563 \\
\hline $\begin{array}{c}\text { Tidak } \\
\text { Cukup }\end{array}$ & $117 / 118$ & $7 / 16$ & 0.992 & 0.438 \\
\hline
\end{tabular}

Sumber: Ningsih \& Hardiyan (2019)

4. Atribut Salah satu/kedua Orang Tua Meninggal Dunia

Tabel5. Probabilitas Salah satu/kedua Orang Tua Meninggal Dunia

\begin{tabular}{|c|c|c|c|c|}
\hline Salah & & & \multicolumn{2}{|c|}{ Probabilitas } \\
\cline { 4 - 5 } $\begin{array}{c}\text { satu/kedua } \\
\text { Orang Tua } \\
\text { Meninggal } \\
\text { Dunia }\end{array}$ & Layak & $\begin{array}{c}\text { Tidak } \\
\text { Layak }\end{array}$ & Layak & $\begin{array}{c}\text { Tidak } \\
\text { Layak }\end{array}$ \\
\hline Ya & $25 / 118$ & $2 / 16$ & 0.212 & 0.125 \\
\hline Tidak & $93 / 118$ & $14 / 16$ & 0.788 & 0.875 \\
\hline
\end{tabular}

Sumber: Ningsih \& Hardiyan (2019)

5. Atribut Status Tempat Tinggal

Tabel 6. Probabilitas Status Tempat Tinggal

\begin{tabular}{|c|c|c|c|c|}
\hline $\begin{array}{c}\text { Status Tempat } \\
\text { Tinggal }\end{array}$ & Layak & $\begin{array}{c}\text { Tidak } \\
\text { Layak }\end{array}$ & Layak & $\begin{array}{c}\text { Tidak } \\
\text { Layak }\end{array}$ \\
\hline Kontrak/sewa & $81 / 118$ & $1 / 16$ & 0.686 & 0.063 \\
\hline Milik Sendiri & $19 / 118$ & $8 / 16$ & 0.161 & 0.5 \\
\hline Bebas Sewa & $18 / 118$ & $7 / 16$ & 0.153 & 0.438 \\
\hline
\end{tabular}


Sumber: Ningsih \& Hardiyan (2019)

6. Atribut Daya Listrik Rumah

Tabel 7. Probabilitas Daya Listri Rumah (Watt)

\begin{tabular}{|c|c|c|c|c|}
\hline $\begin{array}{c}\text { Daya } \\
\text { Listrik } \\
\text { Rumah }\end{array}$ & Layak & $\begin{array}{c}\text { Tidak } \\
\text { Layak }\end{array}$ & Layak & $\begin{array}{c}\text { Tidak } \\
\text { Layak }\end{array}$ \\
\hline 450Watt & $30 / 118$ & $1 / 16$ & 0.254 & 0.063 \\
\hline 950Watt & $61 / 118$ & $8 / 16$ & 0.517 & 0.5 \\
\hline 1300Watt & $27 / 118$ & $7 / 16$ & 0.229 & 0.438 \\
\hline
\end{tabular}

Sumber: Ningsih \& Hardiyan (2019)

\section{Atribut Luas Bangunan Tempat Tinggal}

Tabel 8. Probabilitas Luas Bangunan Tempat Tinggal

\begin{tabular}{|c|c|c|c|c|}
\hline Luas & & & \multicolumn{2}{|c|}{ Probabilitas } \\
\cline { 4 - 5 } $\begin{array}{c}\text { Bangunan } \\
\text { Tempat } \\
\text { Tinggal }\end{array}$ & Layak & $\begin{array}{c}\text { Tidak } \\
\text { Layak }\end{array}$ & Layak & $\begin{array}{r}\text { Tidak } \\
\text { Layak }\end{array}$ \\
\hline $\begin{array}{c}\text { Lebih } \\
\text { dari } 8 \mathrm{~m}^{2}\end{array}$ & $83 / 118$ & $3 / 16$ & 0.703 & 0.188 \\
\hline $\begin{array}{c}\text { Kurang } \\
\text { dari } 8 \mathrm{~m}^{2}\end{array}$ & $35 / 118$ & $13 / 16$ & 0.297 & 0.813 \\
\hline
\end{tabular}

Sumber: Ningsih \& Hardiyan (2019)

\section{d. Menghitung Probabilitas Akhir Setiap Kelas} Untuk menghitung probabilitas akhir pada setiap kelas, perlu menggunakan data training yang sudah diubah nilainya sesuai dengan atribut masingmasing.Lalu dari masing-masing atribut dan nilai probabilitas kelas, dikalikan.

Dari kedua hasil yang sudah ditentukan pada tiap kelas, bandingkan nilai yang paling tinggi.Jika kelas layak bernilai paling tinggi, maka hasilnya layak.Begitu pula sebaliknya.

\section{e. Contoh Kasus Perhitungan Nä̈ve Bayes}

Untuk memudahkan dalam pemahaman perhitungan Naïve Bayes secara manual akan dibuat studi kasus dengan menggunakan salah satu data testing yang dipilih secara random.

Siswi yang bernama AMANDA PISCESSYA kelas 4 SD akan mengajukan Kartu Jakarta Pintar dengan data sebagai berikut:

Tabel 9. Contoh Kasus Data Testing

\begin{tabular}{|l|l|}
\hline $\begin{array}{l}\text { Pendidikan Kepala Rumah } \\
\text { Tangga }\end{array}$ & Lebih dari SMA \\
\hline $\begin{array}{l}\text { Pekerjaan Kepala Rumah } \\
\text { Tangga }\end{array}$ & Tetap \\
\hline $\begin{array}{l}\text { Salah satu/kedua orang tua } \\
\text { meninggal dunia }\end{array}$ & Tidak \\
\hline Status tempat tinggal & Kontrak/sewa \\
\hline Daya Listrik (Watt) & 900 \\
\hline Penghasilan Kepala Rumah & Tidak cukup \\
\hline
\end{tabular}

\begin{tabular}{|l|l|}
\hline Tangga & \\
\hline Luas bangunan tempat tinggal & Lebih dari $8 \mathrm{~m}^{2}$ \\
\hline Status KJP & $?$ \\
\hline
\end{tabular}

Sumber: Ningsih \& Hardiyan (2019)

Data Testing:

$\mathrm{X}=$ (Pendidikan Kepala Rumah Tangga $=$ "Lebih dari SMA", Pekerjaan Kepala Rumah Tangga= "Tetap", Salah satu/kedua orang tua meninggal dunia= "Tidak", penghasilan kepala rumah tangga= "Tidak cukup", status tempat tinggal= "Kontrak/sewa", Daya listrik= "900", luas bangunan tempat tinggal= "lebih dari $8 \mathrm{~m} 2 ")$

$\mathrm{P}(\mathrm{Ci})$

$\mathrm{P}($ Layak $)=0.881$

$\mathrm{P}($ Tidak Layak $=0.119$

$\mathrm{P}(\mathrm{X} \mid \mathrm{Ci})$

$\mathrm{P}($ Pendidikan kepala rumah tangga $=$ "Lebih dari SMA" | Layak) $=0.297$

$\mathrm{P}($ Status pekerjaan kepala rumah tangga= "Tetap" | Layak) $=0.407$

$\mathrm{P}($ Penghasilan kepala rumah tangga $=$ "Tidak Cukup" | Layak) = 0.992

$\mathrm{P}($ Salah satu/kedua orang tua meninggal dunia= "Tidak" | Layak) = 0.788

$\mathrm{P}($ Status tempat tinggal= "kontrak/sewa" $\mid$ Layak $)=$ 0.686

$\mathrm{P}($ Daya listrik $=$ “900” $\mid$ Layak $)=0.517$

$\mathrm{P}($ Luas bangunan tempat tinggal= "lebih dari $8 \mathrm{~m}$ " | Layak) $=0.297$

$$
\begin{aligned}
\mathrm{P}(\mathrm{X} \mid \text { Layak })= & 0.297 \times 0.407 \times 0.992 \times 0.788 \times 0.686 \\
& \times 0.517 \times 0.297 \\
& =0.00995
\end{aligned}
$$

$\mathrm{P}($ Pendidikan kepala rumah tangga $=$ "Lebih dari SMA" $\mid$ Tidak Layak) $=0.875$

$\mathrm{P}($ Status pekerjaan kepala rumah tangga $=$ "Tetap" | Tidak Layak) $=0.875$

$\mathrm{P}($ Penghasilan kepala rumah tangga $=$ "Tidak Cukup" ( Tidak Layak) $=0.438$

$\mathrm{P}$ (Salah satu/kedua orang tua meninggal dunia= "Tidak" | Tidak Layak) = 0.875

$\mathrm{P}($ Status tempat tinggal $=$ "kontrak/sewa" | Tidak Layak) $=0.063$

$\mathrm{P}($ Daya listrik= "900” $\mid$ Tidak Layak $)=0.5$ 
$\mathrm{P}($ Luas bangunan tempat tinggal= "lebih dari $8 \mathrm{~m} "$ Tidak Layak $)=0.813$

$$
\begin{aligned}
\mathrm{P}(\mathrm{X} \mid \text { Tidak Layak }) & =0.875 \times 0.875 \times 0.438 \times 0.875 \times \\
& 0.063 \times 0.5 \times 0.813 \\
= & 0.00751
\end{aligned}
$$

$\mathrm{P}(\mathrm{X} \mid \mathrm{Ci}) * \mathrm{P}(\mathrm{Ci})$

$\mathrm{P}(\mathrm{X} \mid$ Layak $) * \mathrm{P}($ Layak $)=0.0087$

$\mathrm{P}(\mathrm{X} \mid$ Tidak Layak $) * \mathrm{P}($ Tidak Layak $)=0.00089$

Jadi, untuk Pendidikan Kepala Rumah Tangga= "Lebih dari SMA", Pekerjaan Kepala Rumah Tangga $=$ "Tetap", Salah satu/kedua orang tua meninggal dunia $=$ "Tidak", penghasilan kepala rumah tangga $=$ "Tidak cukup", status tempat tinggal= "Kontrak/sewa", Daya listrik= "900", luas bangunan tempat tinggal= "lebih dari $8 \mathrm{~m} 2 "$ ", masuk ke kelas Layak.

\section{Pengujian Akurasi dengan Rapidminer}

Uji coba dilakukan dengan manggunakan data testing yang diambil dari $20 \%$ dari dataset berjumlah 34 data yang dipilih secara random dan data Data training.

Tujuan utama penelitian ini adalah untuk mengetahui nilai akurasi dari algoritma Nä̈ve Bayes yang digunakan untuk mengklasifikasi kelayakan penerima KJP.

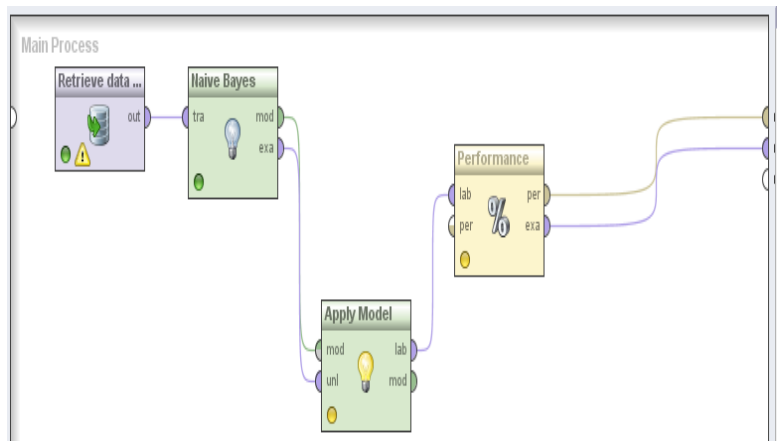

Sumber: Ningsih \& Hardiyan (2019)

Gambar 2. Proses akurasi data training

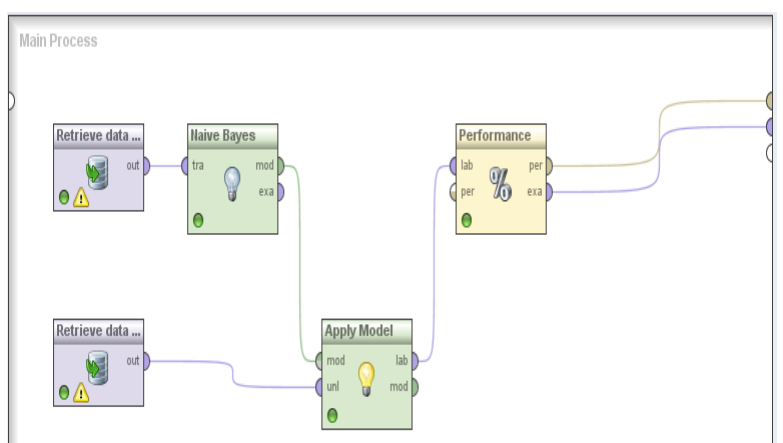

Sumber: Ningsih \& Hardiyan (2019)

Gambar 3. Proses akurasi data testing

Data training diolah dengan algoritma klasifikasi naïve bayes. Kemudian apply model digunakan untuk mengecek data training yang sudah diolah dengan menggunakan model Nä̈ve Bayes tadi digunakan untuk dibandingkan dengan data testing. Performance berfungsi untuk mengetahui kesebaran

\begin{tabular}{|c|c|c|c|}
\hline \multicolumn{4}{|c|}{ (0) Multiclass Classification Performance OAnnotations } \\
\hline \multicolumn{4}{|c|}{ (1) Table View OPlotView } \\
\hline \multicolumn{4}{|l|}{ accuracy: $97,76 \%$} \\
\hline & true LAYAK & true TIDAKLAYAK & class precision \\
\hline pred. LAYAK & 117 & 2 & $98.32 \%$ \\
\hline pred. TIDAK LAYAK & 1 & 14 & $93.33 \%$ \\
\hline class recall & $99.15 \%$ & $87.50 \%$ & \\
\hline
\end{tabular}
data dan mengetahui akurasi dari data training yang telah dibuat dengan menggunakan data testing.

Sumber: Ningsih \& Hardiyan (2019)

Gambar 4. Hasil Akurasi data training

Dari Gambar 4 diatas terlihat bahwa nilai accuracy dari algoritma Nä̈ve Bayes dengan menggunakan data training adalah sebesar 97,76\%. Data training berjumlah 134 data, dan sebanyak 117 data yang dinyatakan 'Layak' diprediksi dengan benar dan sebanyak 14 data yang dinyatakan 'Tidak layak' juga diprediksi dengan benar. Sedangkan 2 data yang menyatakan 'Tidak Layak' diprediksi dengan

\begin{tabular}{|c|c|c|c|}
\hline \multicolumn{4}{|c|}{ (1) Multiclass Classification Performance $\bigcirc$ Annotations } \\
\hline \multicolumn{4}{|c|}{ (0) Table View OPlotView } \\
\hline \multicolumn{4}{|l|}{ accuracy: $100,00 \%$} \\
\hline & true LAYAK & true TIDAKLAYAK & class precision \\
\hline pred. LAYAK & 28 & 0 & $100.00 \%$ \\
\hline pred. TIDAK LAYAK & 0 & 6 & $100.00 \%$ \\
\hline class recall & $100.00 \%$ & $100.00 \%$ & \\
\hline
\end{tabular}
salah dan sebanyak 1 data yang dinyatakan 'Layak' diprediksi juga salah.

Sumber: Ningsih \& Hardiyan (2019)

Gambar 5. Hasil Akurasi data testing

Dari Gambar 5diatas terlihat bahwa nilai accuracy dari algoritma Nä̈ve Bayes dengan data testing adalah sebesar $100 \%$. Data testing berjumlah 34 data, dan sebanyak 28 data dinyatakan 'Layak' diprediksi dengan benar dan sebanyak 6 data yang dinyatakan 'Tidak Layak' juga diprediksi dengan benar.

Hasil analisa menggunakan Rapidminer dengan data training untuk mengetahui akurasinya sebagai berikut:

Jumlah data yang diuji $\quad: 134$

Jumlah data yang diprediksi benar : 131

Jumlah data yang diprediksi salah : 3

Akurasi $=\frac{\text { Jumlah data yang ditorgdiksi banar }}{\text { Jumlah data yang diuji }} \times 100 \%$ 


$$
\begin{aligned}
& =\frac{131}{134} \times 100 \%=97,76 \% \\
\text { Error }= & \frac{\text { Jumlah data yang dịtrdiksi salah }}{\text { Jumlah data yang diuji }} \times 100 \% \\
& =\frac{3}{134} \times 100 \%=2,24 \%
\end{aligned}
$$

Hasil analisa menggunakan Rapidminer dengan data testing untuk mengetahui akurasinya sebagai berikut:

Jumlah data yang diuji $\quad: 34$

Jumlah data yang diprediksi benar : 34

Jumlah data yang diprediksi salah : 0

$$
\begin{aligned}
\text { Akurasi } & =\frac{\text { Jumlah data yang dịtrediksi banar }}{\text { Jumlah data yang diuji }} \times 100 \% \\
& =\frac{34}{34} \times 100 \%=100 \% \\
\text { Etror }= & \frac{\text { Jumlah data yang ditoradiksi salah }}{\text { Jumlah data yang diuji }} \times 100 \% \\
& =\frac{0}{34} \times 100 \%=0 \%
\end{aligned}
$$

Tabel 10. Hasil Akurasi Data Training dan Data Testing

\begin{tabular}{|l|c|c|c|}
\hline \multirow{2}{*}{ Metode } & \multicolumn{2}{|c|}{ Confusion Matrix } & \multirow{2}{*}{ Akurasi } \\
\cline { 2 - 3 } & $\begin{array}{c}\text { Data } \\
\text { Training }\end{array}$ & $\begin{array}{c}\text { Data } \\
\text { Testing }\end{array}$ & \\
\hline $\begin{array}{l}\text { Nä̈ve } \\
\text { Bayes }\end{array}$ & $97,76 \%$ & $100 \%$ & $98,88 \%$ \\
\hline
\end{tabular}

Sumber: Ningsih \& Hardiyan (2019)

Dengan menggunakan perbandingan data training sebesar $80 \%$ dan data testing sebesar $20 \%$ dari perhitungan tersebut dapat disimpulkan bahwa hasil akurasi model nä̈ve bayes menunjukkan tingkat akurasinya $98.88 \%$ artinya prediksi kelayakan penerima KJP menggunakan naïve bayes terbukti baik.

\section{KESIMPULAN}

Berdasarkan hasil penelitian yang telah dilakukan mengenai penentuan kelayakan penerima Kartu Jakarta Pintar Plus dengan menggunakan metode Nä̈ve Bayes di SDN Kembangan Utara 09 Pagi maka dapat diambil beberapa kesimpulan sebagai berikut:

1. Metode algoritmaNä̈ve Bayes memanfaatkan data training untuk menghasilkan probabilitas setiap kriteria untuk class yang berbeda, sehingga nilai-nilai probabilitas dari kriteria tersebut dapat dioptimalkan untuk memprediksi suatu kondisi berdasarkan proses klasifikasi yang dilakukan oleh metode Nä̈ve Bayes itu sendiri.

2. Penerapan metode Nä̈ve Bayes dapat membantu pihak sekolah untuk memprediksi data penerima KJP Plus pada tahap selanjutnya, dengan cara menghitung probabilitas setiap atribut yang sama penting dan setiap atribut saling bebas satu sama lain.

3. Penerapan algoritmaNä̈ve Bayes pada data form survey kelayakan penerima Kartu Jakarta Pintar di SDN Kembangan Utara 09 Pagi memperoleh nilai akurasi yang telah dilakukan dalam aplikasi rapidminer dengan menggunakan data training dan data testing sebesar $98,88 \%$

4. Hasil penelitian ini adalah Metode Nä̈ve Bayes dapat mempermudah pihak SDN Kembangan Utara 09 Pagi dalam menentukan siapa saja siswa yang layak mendapatkan Kartu Jakarta Pintar Plus (KJPPlus).

\section{REFERENSI}

Bustami. (2014). Penerapan Algoritma Naive Bayes untuk Mengklasifikasi Data Nasabah Asuransi.Jurnal Informatika, 8(1), 884-898. Diambil dari https://doi.org/10.1364/OFC.2009.OWD2

Dahri, D., Agus, F., \& Khairina, D. M. (2016).Metode Naive Bayes Untuk Penentuan Penerima Beasiswa Bidikmisi Universitas Mulawarman.Informatika Mulawarman: Jurnal Ilmiah Ilmu Komputer, 11(2), 29. Diambil dari http://ejournals.unmul.ac.id/index.php/JIM/article/vie $\mathrm{w} / 211$

Putri, R. E., Suparti, \& Rahmawati, R. (2014). PERBANDINGAN METODE KLASIFIKASI NAÏVE BAYES DAN K-NEAREST NEIGHBOR PADA ANALISIS DATA STATUS KERJA DI KABUPATEN DEMAK TAHUN 2012. JURNAL GAUSSIAN, 3(November), 831-838. Diambil dari https://media.neliti.com/media/publications/17 4993-ID-penentuan-bonus-pada-karyawandengan-men.pdf

Saryoko, A. (2017). PENENTUAN PENERIMA KARTU JAKARTA PINTAR DENGAN METODE ANALYTICAL HIERARCHY PROCESS. In Perspektif. Diambil dari https://ejournal.bsi.ac.id/ejurnal/index.php/pers pektif/article/view/1331

Suntoro, J. (2019). Data Mining: Algoritma dan Implementasi dengan Pemograman PHP. Jakarta: PT Elex Media Komputindo. 